\title{
A noção de corpo de Cristo em Joseph Ratzinger e os seus fundamentos na eclesiologia recente
}

\author{
Orientador: Antonio Luiz Catelan Ferreira \\ Mestrando: Max de Araújo Cardoso \\ Área de Concentração: Teologia Sistemático-Pastoral \\ Linha de Pesquisa: Fé e Cultura \\ Projeto de Pesquisa: A teologia de Joseph Ratzinger - Bento XVI
}

A partir da análise da renovação da eclesiologia que ocorreu na história da teologia a partir do século XIX com o consequente redescobrimento da noção de Igreja como Corpo de Cristo, buscamos nessa pesquisa mostrar como se deu o desenvolvimento desse conceito na renovação da eclesiologia no século XIX, partindo da eclesiologia de Möhler, passando pelos teólogos da Escola de Roma influenciados por ele e mostrando as bases colocadas pelo Magistério da época, principalmente no Concílio Vaticano I. Analisamos também de que maneira se seguiu a reflexão teológica do conceito de Corpo de Cristo nos diversos momentos que a teologia passou no início do século XX, chegando até a encíclica Mystici Corporis de Pio XII e a sua influência no Concílio Vaticano II, principalmente na redação da encíclica Lumen Gentium. A partir dessa compreensão da evolução da noção Corpo de Cristo na eclesiologia recente concluímos o trabalho analisando a contribuição de Joseph Ratzinger que dá luzes importantes para compreender como a noção de Corpo de Cristo nos ajuda a entender melhor a própria natureza da Igreja.

Palavras-chave: Eclesiologia. Corpo de Cristo. Mystici Corporis. Joseph Ratzinger. 